Federal Reserve Bank of Dallas

Globalization and Monetary Policy Institute

Working Paper No. 306

https://www.dallasfed.org/ /media/documents/institute/wpapers/2017/0306.pdf

\title{
Trade Uncertainty and Income Inequality ${ }^{*}$
}

\author{
Markus Brueckner \\ Australian National University \\ Joaquin Vespignani \\ University of Tasmania
}

March 2017

\begin{abstract}
This paper examines the relationship between trade uncertainty and income inequality. In countries where only a small share of the population is educated, an increase in trade uncertainty is associated with a significant increase in income inequality. As education of the population increases the relationship between trade uncertainty and income inequality becomes more muted. Trade uncertainty has no significant effect on income inequality in countries that are world leaders in education. Developing countries that want to reduce income inequality arising from trade uncertainty should therefore consider further improving their education system.
\end{abstract}

JEL codes: F1, E2

\footnotetext{
* Markus Brueckner, Australian National University, LF Crisp Building, Room 2062A, ACT 0200, Australia.61-2-6125-3881. markus.brueckner@anu.edu. Joaquin Vespignani, University of Tasmania, Tasmanian School of Business and Economics, Room 114, Centennial Building, Sandy Bay Campus, Australia.61-3-6226-2802. Joaquin.Vespignani@utas.edu.au. The views in this paper are those of the authors and do not necessarily reflect the views of the Federal Reserve Bank of Dallas or the Federal Reserve System.
} 


\section{Introduction}

Trade uncertainty is the exchange of goods and services that is not determined by fundamentals. In the spirit of this definition we construct a measure of bilateral trade uncertainty between the United States and 154 countries. Our econometric model relates income inequality to trade uncertainty, education, and the interaction between trade uncertainty and education. A novel result from our empirical analysis is that education significantly affects the relationship between trade uncertainty and income inequality. In countries where only a small share of the population is educated, an increase in trade uncertainty is associated with a significant increase in income inequality. As education of the population increases the positive correlation between trade uncertainty and income inequality becomes smaller. There is no significant positive relationship between trade uncertainty and income inequality in countries that are leaders in education.

The measure of trade uncertainty is constructed as the residual from a gravity equation. Following Head et al. (2010), the variables entering the gravity equation measure geographic, cultural, and historical characteristics of countries. The data are publicly available, i.e. every person in the world who has access to the internet can use them. Our definition of uncertainty -- the part of economic activity that is not determined by fundamentals -- is related to the work of Jurado et al. (2015). Jurado et al. (2015) define uncertainty as an unforecastable component of a linear estimation. This definition of uncertainty is different from Bloom (2009) and Baker et al. (2016). These authors compute a measure of uncertainty based on major shocks such as the Cuban missile crisis and the assassination of JFK. The authors analyse the macroeconomic impact of their uncertainty measure using relatively high frequency data. Such high frequency data are not available for income inequality.

In our empirical analysis we consider both the quantity and quality of education. The quantity of education is measured by the share of the population with primary schooling. The data are from the World Bank (2016). Data on quality of education are from Hanushek and Woessman (2009). The quality of education is measured by the average of pupils' PISA tests scores. The econometric analysis shows that both quantity and quality of education matter for the relationship between trade uncertainty and income inequality. Conditional on the quality of education, a larger share of the population with schooling significantly attenuates towards zero 
the relationship between trade uncertainty and income inequality. The same holds for the quality of education: Conditional on the quantity of education, a higher value of average test scores significantly attenuates towards zero the positive relationship between trade uncertainty and income inequality.

An explanation for why education affects the relationship between trade uncertainty and income inequality is that education matters for individuals' ability to bargain. Better educated people tend to have better bargaining skills. The stronger the extent of trade uncertainty, the less it can be specified in contracts how the gains from trade are divided, i.e. contract incompleteness is an increasing function of trade uncertainty. Bargaining skills are thus particularly important when trade uncertainty is high. When only a small share of the population is educated, unexpected gains from trade will be unequally distributed. That is why trade uncertainty increases inequality in countries where only a small share of the population is educated.

When we estimate our econometric model substituting trade uncertainty for bilateral trade we find that the coefficient on trade is statistically insignificant and quantitatively small. Regardless of education, trade has an insignificant effect on income distribution. This suggests that it is not trade per se but rather the component of trade unrelated to fundamentals that matters for income inequality. Literature on trade openness and inequality is summarized by Harrison et al. (2011).

Another contribution of our paper is to document that inequality is significantly related to education. Income inequality is significantly lower in countries with a better educated population. This result is consistent with theoretical models, such as, Galor and Zeira (1993) and Galor and Moav (2004), where investment in human capital is the mechanism through which income distribution affects aggregate output.

The remainder of the paper is organized as follows. Section 2 discusses the estimation strategy and data. Section 3 presents estimation results. Section 4 concludes.

\section{Estimation Strategy}

2.1 The Gravity Model and Trade Uncertainty 
This section discusses estimation of a gravity model for bilateral trade. Following the work of Head et al. (2010) the equation is:

$$
\begin{aligned}
& \log \left(\frac{\text { Bilateral Trade }_{G D P}}{G \text { it }}=\beta_{0}+\alpha \log \left(\text { Population }_{i t}\right)+\gamma \log \left(\text { Distance }_{i}\right)+\delta \log \left(\text { Area }_{i}\right)+\right. \\
& \text { BBorder }_{i}+\varphi \text { Locked }_{i}+\tau \text { Language }_{i}+\rho \text { Colonial }_{i}+\text { ofreetrade }_{i t}+\epsilon
\end{aligned}
$$

Where $\log (\text { Bilateral Trade/GDP })_{\text {it }}$ is the ratio of exports plus imports between country $i$ and the United States, divided by nominal GDP of country $i$. Population $n_{\text {it }}$ is the country's population. Distance $\mathrm{i}_{\mathrm{i}}$ is the distance of country $i$ to the US (measured in kilometres). Area $\mathrm{a}_{\mathrm{i}}$ is the country's area (measured in square kilometres). Border $r_{i}$ is a dummy for countries that share a border with the US. Locked ${ }_{i}$ is a dummy variable for landlocked countries. Colonial ${ }_{i}$ is a dummy variable for ex-British colonies. Freetrade $e_{i t}$ is a dummy variable for countries with free trade agreement with the US (dates for free trade agreements are described in Data Appendix Table 2). The coefficients $\beta_{0}, \alpha, \gamma, \delta, \theta, \varphi, \tau, \rho$ are parameters to be estimated and $\epsilon$ is an error term. Full data description and sources for all variables can be found in Data Appendix Table 1. A list of the 154 countries used in this unbalanced panel estimation can be found in Data Appendix Table 5.

Following Jurado et al (2015) in defining uncertainty as an unforecastable component of a linear estimation we compute a residual based on the estimates of Equation 1. Trade uncertainty is thus the variation of the log of bilateral trade/nominal GDP that cannot be explained by variables that the trade literature has found to be significant determinants of trade.

\subsection{The Impact of Trade Uncertainty and Education on Inequality}

In this section we describe the econometric model that we use to estimate the impact of trade uncertainty (derived from Equation 1) on inequality:

Gini $_{i t}=\beta_{0}+\pi$ Trade Uncertainty $_{i}+\omega$ Quality of Education Ed $_{i}+\lambda$ Quantity of Education $_{i}$ + vTrade Uncertainty $_{\mathrm{i}} *$ Quality of Education ${ }_{i}+\chi$ Trade Uncertainty $_{i} *$ Quantity of Education E $_{i} \varepsilon$

Where Gini $_{i t}$ is a measure of inequality; Trade Uncertainty $y_{i}$ is the inter-temporal mean of the residual from Equation 1. Quality of Education $\mathrm{i}_{\mathrm{i}}$ is from Hanushek and Woessmann (2009). 
Four different measures are used: Cognitive skills, lower secondary education, basic education and top education. Quantity of Education $n_{\mathbf{i}}$ is the inter-temporal mean of the adjusted enrolment rate of primary school. The coefficients $\beta_{0}, \pi, \omega, \lambda, v, \chi$ are parameters to be estimated and $\epsilon$ is an error term. Data description for all variables can be found in Data Appendix Table 3.

Data available for both inequality and quantity of education is lumpy in nature and the only data on quality of education is time invariant. Therefore, with the main objective of preserving a minimal degree of freedom necessary for a robust estimation, an inter-temporal mean model is used.

\section{Results}

\subsection{The Gravity Model}

Table 1 presents estimates of the gravity model. Results are similar to those obtained by Head et al. (2010). The coefficient on the log of population is positive and has an elasticity close to unity. The negative coefficient on distance indicates that geographical distance between countries reduces bilateral trade; the estimated elasticity is around -1.5 . The negative coefficient on the log of area means that larger countries trade less across borders. The coefficient on the border dummy indicates that countries with shared borders with the US (Canada and Mexico) have on average $43 \%$ more bilateral trade with the US relative to all other countries. Countries with open sea access (dummy=0) double their bilateral trade with the US relative to land locked countries (dummy=1). Countries in which English is the official language trade on average $80 \%$ more with the US relative to countries in which the official language is not English. The coefficient associated with colonial trade ties is statistically insignificant; this is in line with Head et al (2010)'s view that colonial trade ties have eroded after World War II. The positive coefficient on the dummy variable for free trade agreement indicates that on average countries with enforced free trade agreement with the US have much higher bilateral trade with the US, by a factor of 1.5 , relative to countries without free trade agreement with the US.

\subsection{Trade Uncertainty and Inequality}


Table 2 presents estimates of the econometric model specified in Equation 2. The $\mathrm{R}^{2}$ of the estimated model is around 0.5 ; this means that up to half of the variation in inequality can be explained in the baseline model by trade uncertainty, education, and the interaction between trade uncertainty and education.

In the first row of Table 2, the coefficient on trade uncertainty is reported. This coefficient is positive and significantly different from zero at the $1 \%$ level. From the second and third row of Table 2 one can see that both the quantity and quality of education are significantly negatively related to inequality. The coefficient on the interaction term between trade uncertainty and quality of education is negative and statistically significant at the 1 percent level.

To facilitate interpretation, it is useful to compute the marginal effect of trade uncertainty on the Gini index. Based on the estimates in Table 2 this yields:

$$
\left.\frac{\partial G \text { ini }}{\text { dTrade Uncertainty }}=26.85-2.59 \text { (Quality of Educ. }\right)-0.15 \text { (Quantity of Educ.) }
$$

From the above equation one can see that the marginal effect of trade uncertainty on the Gini is a decreasing function of education. Table 3 lists these effects for each country based on countries' values of quality and quantity of education that are present in the sample. As one can see, for countries with low values of education trade uncertainty has a large positive effect on the Gini that is significantly different from zero at the 5 percent level or higher. For countries with relatively high values of education there is no significant effect.

To further facilitate interpretation of equation (3) Figures 1a and $1 \mathrm{~b}$ plot the marginal effect, $\frac{\partial G i n i}{\partial \text { Trade Uncertainty }}$, on the y-axis and sample values of education on the x-axis. In Figure 1a the marginal effect is plotted for different values of the quality of education (setting quantity of education at the mean value). One can see that at the sample minimum of the quality of education the marginal effect is around 6 while at sample maximum it is around 0. In Figure $1 \mathrm{~b}$ the marginal effect is plotted for different values of the quantity of education (setting quality of education at the mean value). One can see that at the sample minimum of the quantity of education, the marginal effect is around 13 while at sample maximum it is around 0 . Thus, differences in the quantity of education have a larger impact on the effect that trade uncertainty has on income inequality than differences in the quality of education. 
World leaders have recognized the importance of increasing basic education in development countries (see e.g. Hillman and Junker, 2004). Throughout the past two decades, Low Income Countries made significant progress in terms of increasing the share of the population with primary education: in the 1980s and early 1990s the average enrolment rate in primary school was below 50\%; by the 2010s it was nearly $80 \%$. Figure 2 shows that based on the estimates of equation (3), a one unit increase in trade uncertainty was associated in Low Income Countries with an about 9 percentage points increase in the Gini coefficient during the 1980s. By the 2010s this effect was below 6 percentage points. For comparison, in the group of Middle (High) Income Countries the effect was around 4 (0) percentage points during the 1980s and below 3 (0) percentage points by the 2010s. The significant progress in primary school enrolment in Low Income Countries thus contributed to a substantial decrease in the impact that trade uncertainty had on income inequality in this group of countries.

It is noteworthy that according to Table 2 more education is associated with significantly less income inequality (and more so in countries with greater trade uncertainty). The coefficient on the quality of education is around -10.64; for quantity of education it is 0.17. Both coefficients are significantly different from zero at the conventional significance levels. Quantitatively, the effect that education has on income inequality is sizable. For example, when the measure of trade uncertainty is set equal to zero, a 1 standard deviation $(0.5)$ increase in the quality of education is associated with a decline in the Gini of around 5 percentage points; a 1 standard deviation (16) increase in the quantity of education is associated with a decline in the Gini of around 2.5 percentage points.

\subsection{Robustness}

\subsubsection{Alternative Measures of the Quality of Education}

Table 4 shows estimations of the model for three alternative measures of the quality of education: lower secondary, basic education and top education (see data Appendix for full descriptions). The coefficients on the interactions with trade uncertainty are negative and significantly different from zero at the 1 percent level for all three measures of the quality of education. In terms of overall explanatory power, the model with top education performs much worse than the models with lower secondary or basic education: the R-squared is around 0.49 in columns (1) and (2) and around 0.36 in column (3). 


\subsubsection{Share of Income of the Poorest 20\%}

In Table 5 we report estimates where the dependent variable is the share of income of the poorest $20 \%{ }^{1}$ This measure of income inequality is inversely related to the Gini index: while an increase in the Gini means that inequality increases an increase in the share of income accrued by the poorest $20 \%$ means that inequality decreases.

Table 5 shows that trade uncertainty is associated with a decline in the share of income held by the poorest $20 \%$. The coefficient on trade uncertainty is significantly negative; the coefficients on the interaction between trade uncertainty and education are significantly positive. Trade uncertainty therefore reduces the income share of the poor but less so in countries where a greater share of the population are educated.

\subsubsection{Alternative Time Periods}

Table 6 shows estimation results for alternative time periods. In column (1) results are shown for the full sample period 1981-2013; in columns (2)-(4) results are shown for the subsample periods 1990-2013, 2000-2013, and 2005-2013, respectively. One can see that the coefficients on the right-hand-side variables do not change substantially in terms of magnitude or statistical significance across these sub-samples. The R-squared is around 0.5 in all sub-samples considered.

\subsubsection{Further robustness checks}

In this section we document further robustness checks of our benchmark model. The robustness checks are reported in Table 7: columns (1) and (2) show estimates for models with time fixed effects and random time effects, respectively; in columns (3)-(6) results are shown for estimations with different control variables: (3) GDP per capita, (4) GDP per worker, (5) capital-labour ratio, and (6) internet access. Lastly, in columns (7) and (8), estimations with alternative gravity models are reported including: in column (7) an autoregressive process of order 1; and in column (8) an additional dummy variable for currencies pegged to the US dollar

\footnotetext{
${ }^{1}$ We also estimated the model with the share of income held by the poorest $10 \%$ as dependent variable. Results are similar in terms of sign, magnitude and statistical significance to those reported in Table 5. Results are not reported and are available upon request from the authors.
} 
(8). The interaction between the control variables and trade uncertainty are also included in these estimations. The main result from the robustness analysis is that the coefficient on trade uncertainty is significantly positive; the coefficient on the interaction between trade uncertainty and education is significantly negative. The adjusted R-squared continues to be around 0.5 in all of these specifications suggesting that not much additional explanatory power is gained from these alternative model specifications.

\section{Conclusion}

This study investigated the unexplored influence of trade uncertainty and its interaction with education on income inequality. For this purpose a panel data model was estimated for 61 countries for the period 1981-2013. Results show that, on average, trade uncertainty increases inequality while both quantity and quality of education reduce inequality. Using a model that includes an interaction term between education and trade uncertainty, it is observed that education reduces the impact of trade uncertainty on inequality: in countries that perform poorly along various measures of education, greater trade uncertainty is associated with a large increase in income inequality; in countries that are leaders in education, trade uncertainty has no significant effect on income inequality. Developing countries have made significant progress throughout the past two decades in increasing the quantity of basic education: According to our findings this has significantly contributed to reducing the impact of trade uncertainty on income inequality in these countries. 


\section{References}

Acemoglu, Daron, David Laibson and John A. List. 2014. "Equalizing Superstars: The Internet and the Democratization of Education." American Economic Review, 104 (5), pp. 523-27.

Baker, S., N. Bloom, and S. Davis, 2016, “Measuring Economic Policy Uncertainty," Quarterly Journal of Economics 131: 1593-1636.

Bloom, N., 2009, “The Impact of Uncertainty Shocks.” Econometrica 77: 623-685.

Head, K., Mayer, T., and Ries, J, 2010. "The Erosion of Colonial Trade Linkages after Independence," Journal of International Economics, Vol. 81 (1), pp. 1-14.

Harrison, A., J. McLaren, M. McKillan, 2011, "Recent Perspectives on Trade and Inequality," Annual Review of Economics 3: 261-289.

Jurado, K.., Ludvigson, S.C., and Ng, S, 2015."Measuring Uncertainty," American Economic Review, Vol. 105 (3), pp. 1177-1216.

Galor, O., and J. Zeira, 1993, "Income Distributions and Macroeconomics," Review of Economic Studies 60: 35-52.

Galor, O., and O. Moav, 2004, "From Physical to Human Capital: Inequality and the Process of Development," Review of Economic Studies 71: 1001-1026.

Hanushek, E. and L. Woessmann, 2012, "Do Better Schools Lead to more Growth? Cognitive skills, economic outcomes, and causation," Journal of Economic Growth, Vol. 17 (4), pp. 267321.

Hillman, A. and E. Jenker, 2004, "Educating Children in Poor Countries," IMF Economic Issues, Vol 33.

Ilzetski, E., Reinhart, C. and Rogoff, K., (2010). The Country Chronologies and Background Material to Exchange Rate Arrangements into the 21st Century: Will the Anchor Currency Hold? Unpublished manuscript.

Novy, D., 2013. "International trade without CES: Estimating Translog Gravity," Journal of International Economics, vol. 89(2), pp 271-282.

World Bank, 2016, "World Development Indicators. Available for download at http://data.worldbank.org/data-catalog/world-development-indicators 


\section{Figure 1. Effect of Trade Uncertainty on Inequality}

a.

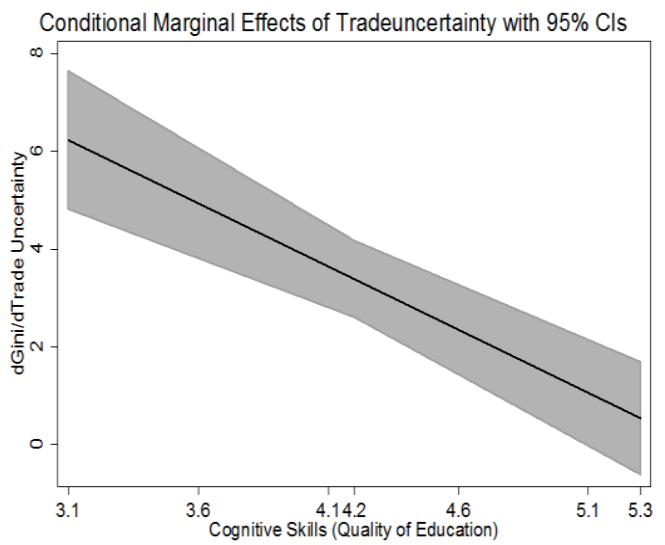

b.

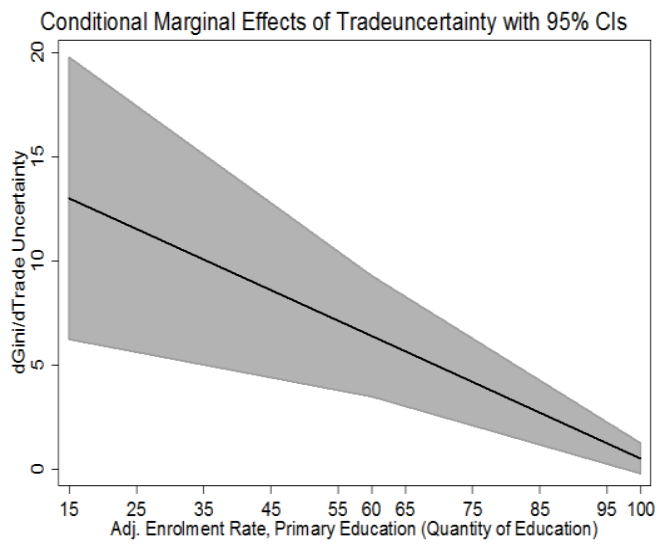

The figure is based on equation (3). Figure 1a plots the effect of trade uncertainty on inequality (y-axis) against sample values of the quality of education (x-axis); quantity of education is set at sample mean. Figure 1b plots the effect of trade uncertainty on inequality ( $\mathrm{y}$-axis) against sample values of the quantity of education (x-axis); quality of education is set at sample mean. 
Figure 2: Effect of Trade Uncertainty on Inequality

(Low, Middle, and High Income Countries)

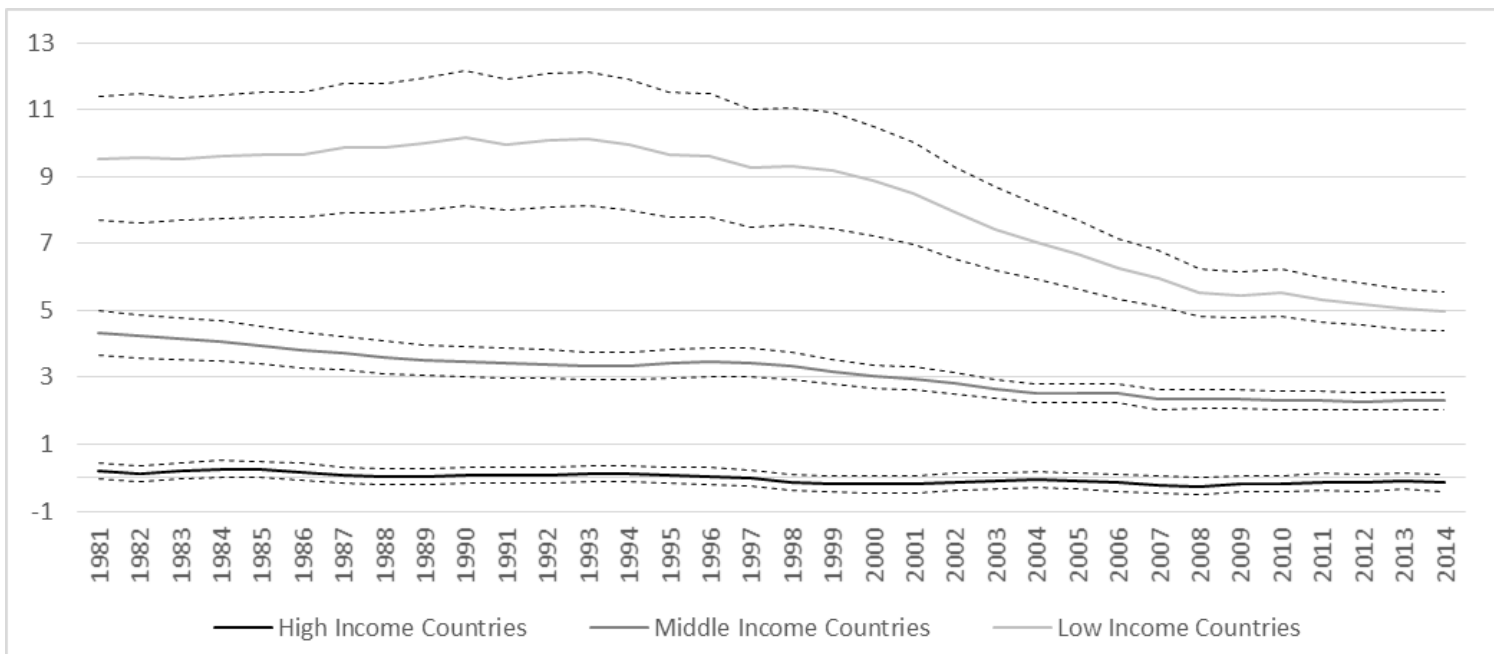

The figure is based on equation (3). To generate the figure: (i) the quality of education parameter (cognitive skills) has been fixed at the average sample value for high income countries (4.95), middle income countries (4.33), and low income countries (3.88); (ii) primary school enrolment rates are used for the (group average) values for different years (time-variant). Income groups are per World Bank definition. 
Table 1: Determinants of Bilateral Trade/GDP

\begin{tabular}{lc}
\hline Dependant Variable: Log(Bilateral Trade/GDP) \\
\hline Log(Population) & $0.957 * * *$ \\
Log(Distance) & $(0.016)$ \\
Log(Area) & $(0.074 *)$ \\
Border & $-0.072^{* * *}$ \\
& $(0.014)$ \\
Locked & $0.357 * *$ \\
& $(0.175)$ \\
Language & $-0.976 * * *$ \\
& $(0.038)$ \\
Colonial & $0.760 * * *$ \\
& $(0.033)$ \\
Freetrade & -0.093 \\
& $(0.087)$ \\
R2 & $1.649 * * *$ \\
Adj R2 & $(0.106)$ \\
Observations & 0.59 \\
Periods (Years) & 0.59 \\
Cross section (Countries) & 3782 \\
\hline
\end{tabular}

Note: Huber robust standard errors (shown in parentheses) are clustered at the country level. *** and $* *$ denotes significance at the $1 \%$ and $5 \%$ level, respectively. 
Table 2: Trade Uncertainty, Education, and Inequality Dependant Variable: Gini Index

\begin{tabular}{lc}
\hline Trade Uncertainty & $26.856^{* * *}$ \\
& $(2.621)$ \\
Quality of Education & $-10.826 * * *$ \\
& $(0.864)$ \\
Quantity of Education & $-0.165^{* *}$ \\
& $(0.067)$ \\
Trade Uncertainty * Quality of Education & $-2.587 * * *$ \\
& $(0.552)$ \\
Trade Uncertainty * Quantity of Education & $-0.147 * * *$ \\
& $(0.031)$ \\
\hline R2 & 0.501 \\
Adj R2 & 0.497 \\
Observations & 635 \\
Periods (Years) & 32 \\
Cross section (Countries) & 61 \\
\hline
\end{tabular}

Note: Huber robust standard errors (shown in parentheses) are clustered at the country level. *** and ** denotes significance at the $1 \%$ and $5 \%$ level, respectively. 
Table 3: Predicted Effect of Trade Uncertainty on the Gini coefficient for Individual Countries

\begin{tabular}{|c|c|c|c|c|c|c|c|}
\hline Country & $\begin{array}{c}\text { Quantity of } \\
\text { Edu. }\end{array}$ & $\begin{array}{l}\text { Quality } \\
\text { of Edu. }\end{array}$ & $\begin{array}{c}\text { Predicted } \\
\text { Effect }\end{array}$ & Country & $\begin{array}{c}\text { Quantity of } \\
\text { Edu. }\end{array}$ & $\begin{array}{l}\text { Quality } \\
\text { of Edu. }\end{array}$ & $\begin{array}{l}\text { Predicted } \\
\text { Effect }\end{array}$ \\
\hline Morocco & 72.26 & 3.33 & $7.64 * * *$ & Israel & 97.53 & 4.69 & 0.41 \\
\hline Ghana & 70.62 & 3.60 & $7.18 * * *$ & Bulgaria & 96.80 & 4.79 & 0.28 \\
\hline Nigeria & 66.72 & 4.15 & $6.33 * * *$ & Lithuania & 97.23 & 4.78 & 0.24 \\
\hline Brazil & 83.16 & 3.58 & $5.39 * * *$ & Malaysia & 96.54 & 4.84 & 0.19 \\
\hline South Africa & 91.96 & 3.09 & $5.37 * *$ & Russia Fed. & 95.50 & 4.92 & 0.13 \\
\hline Peru & 92.18 & 3.13 & $5.23^{* *}$ & Latvia & 97.74 & 4.80 & 0.10 \\
\hline Philippines & 92.37 & 3.65 & $3.86 * * *$ & Ireland & 94.85 & 4.99 & 0.03 \\
\hline Colombia & 83.55 & 4.15 & $3.87 * * *$ & Italy & 99.26 & 4.76 & 0.00 \\
\hline Albania & 92.30 & 3.79 & $3.51 * *$ & Hungary & 94.85 & 5.05 & -0.10 \\
\hline Botswana & 96.01 & 3.64 & $3.35^{* *}$ & Norway & 98.83 & 4.83 & -0.13 \\
\hline Turkey & 94.68 & 3.79 & $3.16^{* *}$ & Poland & 98.81 & 4.84 & -0.15 \\
\hline Indonesia & 96.47 & 3.88 & $2.67 * *$ & Austria & 94.42 & 5.09 & -0.15 \\
\hline Chile & 93.68 & 4.05 & $2.63 * *$ & Spain & 99.67 & 4.83 & -0.25 \\
\hline Macedonia & 93.03 & 4.15 & $2.47 * * *$ & Slovenia & 96.98 & 4.99 & -0.27 \\
\hline Armenia & 88.69 & 4.43 & $2.38 * * *$ & Denmark & 97.91 & 4.96 & -0.34 \\
\hline Iran & 92.60 & 4.22 & $2.35 * *$ & Iceland & 98.59 & 4.94 & -0.37 \\
\hline Uruguay & 91.34 & 4.30 & $2.33 * * *$ & Slovak Rep. & 96.51 & 5.05 & -0.37 \\
\hline Mexico & 96.71 & 4.00 & 2.32 & UK & 98.62 & 4.95 & -0.41 \\
\hline Tunisia & 94.43 & 4.13 & $2.32 * *$ & Australia & 96.21 & 5.09 & -0.43 \\
\hline Argentina & 98.43 & 3.92 & 2.28 & Belgium & 97.24 & 5.04 & -0.44 \\
\hline Egypt & 96.63 & 4.03 & 2.25 & Netherland & 96.11 & 5.11 & -0.47 \\
\hline India & 92.77 & 4.28 & $2.17 * *$ & Germany & 99.14 & 4.96 & -0.50 \\
\hline Cyprus & 88.92 & 4.54 & $2.07 * * *$ & Canada & 96.47 & 5.13 & -0.54 \\
\hline Jordan & 96.38 & 4.26 & 1.70 & France & 98.03 & 5.04 & -0.55 \\
\hline Moldova & 92.41 & 4.53 & $1.58 * *$ & Switzerland & 98.75 & 5.01 & -0.59 \\
\hline Portugal & 92.02 & 4.56 & $1.56^{* *}$ & Sweden & 98.74 & 5.01 & -0.59 \\
\hline Luxembourg & 91.51 & 4.64 & $1.43 * *$ & Swaziland & 97.02 & 5.14 & -0.66 \\
\hline Romania & 95.31 & 4.56 & 1.07 & Estonia & 96.82 & 5.19 & -0.77 \\
\hline Serbia & 97.35 & 4.45 & 1.06 & Finland & 98.57 & 5.13 & -0.87 \\
\hline Greece & 96.48 & 4.61 & 0.77 & Japan & 99.92 & 5.31 & -1.54 \\
\hline China & 92.50 & 4.94 & 0.50 & & & & \\
\hline
\end{tabular}

Note: $* * *$ and $* *$ denotes that the predicted (percentage point) effect on the Gini coefficient of a 1 unit increase in trade uncertainty is significantly different from zero at the $1 \%$ and $5 \%$ level, respectively. 
Table 4: Trade Uncertainty, Education, and Inequality Dependant Variable: Gini Index

\begin{tabular}{lccc}
\hline & \multicolumn{3}{c}{ Measure of Quality of Education } \\
\cline { 2 - 4 } & $\begin{array}{c}\text { Lower Secondary } \\
\text { Education }\end{array}$ & Basic Education & Top Education \\
& $(1)$ & $(2)$ & $(3)$ \\
\cline { 2 - 4 } Trade Uncertainty & $26.869^{* * *}$ & $18.069 * * *$ & $17.989 * * *$ \\
& $(2.707)$ & $(3.242)$ & $(1.965)$ \\
Quality of Education & $-10.073^{* * *}$ & $-26.908^{* * *}$ & $-134.77 * * *$ \\
& $(0.856)$ & $(2.055)$ & $(13.705)$ \\
Quantity of Education & $-0.148^{* *}$ & $-0.259 * * *$ & $-0.128^{* *}$ \\
& $(0.072)$ & $(0.062)$ & $(0.064)$ \\
Trade Uncertainty & $-2.161^{* * *}$ & $-9.829 * * *$ & $-17.044 * * *$ \\
$*$ Quality of Education & $(0.354)$ & $(1.428)$ & $(5.481)$ \\
Trade Uncertainty & $-0.170^{* * *}$ & $-0.098 * * *$ & $-0.169 * * *$ \\
$*$ Quantity of Education & $(0.035)$ & $(0.039)$ & $(0.021)$ \\
\hline R2 & 0.490 & 0.486 & 0.364 \\
Adj R2 & 0.486 & 0.481 & 0.359 \\
Observations & 635 & 635 & 635 \\
Periods (Years) & 32 & 32 & 32 \\
Cross section (Countries) & 61 & 61 & 61 \\
\hline
\end{tabular}

Note: Huber robust standard errors (shown in parentheses) are clustered at the country level. *** and $* *$ denotes significance at the $1 \%$ and $5 \%$ level, respectively. 
Table 5: Trade Uncertainty, Education, and Inequality

Dependant Variable: Income Held by the Poorest $20 \%$

\begin{tabular}{lc}
\hline Trade Uncertainty & $-5.348 * * *$ \\
Quality of Education & $(0.435)$ \\
& $2.170 * * *$ \\
Quantity of Education & $(0.114)$ \\
& $0.021 * *$ \\
Trade Uncertainty* Quality of Education & $(0.009)$ \\
Trade Uncertainty* Quantity of Education & $0.540 * * *$ \\
& $0.028 * * *$ \\
\hline R2 & $(0.004)$ \\
Adj R2 & 0.418 \\
Observations & 0.413 \\
Periods (Years) & 636 \\
Cross section (Countries) & 32 \\
\hline
\end{tabular}

Note: Huber robust standard errors (shown in parentheses) are clustered at the country level. *** and $* *$ denotes significance at the $1 \%$ and $5 \%$ level, respectively. 
Table 6: Trade Uncertainty, Education, and Inequality Dependant Variable: Gini Index

\begin{tabular}{lcccc}
\hline & \multicolumn{4}{c}{ Subsamples } \\
\cline { 2 - 5 } & $1981-2013$ & $1990-2013$ & $2000-2013$ & $2005-2013$ \\
& $(1)$ & $(2)$ & $(3)$ & $(4)$ \\
\cline { 2 - 5 } Trade Uncertainty & $26.856^{* * *}$ & $27.417 * * *$ & $24.634 * * *$ & $23.239 * * *$ \\
& $(2.621)$ & $(2.734)$ & $(2.622)$ & $(2.130)$ \\
Quality of Education & $-10.827 * * *$ & $-9.777 * * *$ & $-9.707 * * *$ & $-9.171 * * *$ \\
& $(0.863)$ & $(0.477)$ & $(0.384)$ & $(0.470)$ \\
Quantity of Education & $-0.165 * * *$ & $-0.242 * * *$ & $-0.255^{* * *}$ & $-0.265 * * *$ \\
& $(0.064)$ & $(0.052)$ & $(0.050)$ & $(0.040)$ \\
Trade Uncertainty & $-2.587 * * *$ & $-3.275 * * *$ & $-3.424 * * *$ & $-3.267 * * *$ \\
$*$ Quality of Education & $(0.552)$ & $(0.312)$ & $(0.212)$ & $(0.206)$ \\
& & & & \\
Trade Uncertainty & $-0.147 * * *$ & $-0.120 * * *$ & $-0.084 * * *$ & $-0.077 * * *$ \\
$*$ Quantity of Education & $(0.031)$ & $(0.032)$ & $(0.024)$ & $(0.019)$ \\
\hline R2 & 0.502 & 0.546 & 0.572 & 0.564 \\
Adj R2 & 0.497 & 0.542 & 0.568 & 0.557 \\
Observations & 635 & 584 & 467 & 344 \\
Periods (Years) & 32 & 24 & 14 & 9 \\
Cross Section (Countries) & 61 & 61 & 61 & 60 \\
\hline
\end{tabular}

Note: Huber robust standard errors (shown in parentheses) are clustered at the country level. $* * *$ and $* *$ denotes significance at the $1 \%$ and $5 \%$ level, respectively. 
Table 7: Trade Uncertainty, Education, and Inequality

\begin{tabular}{|c|c|c|c|c|c|c|c|c|}
\hline & \multicolumn{2}{|c|}{ Alternative Est. Methods } & \multicolumn{4}{|c|}{ Additional Control Variables } & \multicolumn{2}{|c|}{ Alternative Gravity Equation } \\
\hline & (1) & (2) & (3) & (4) & $(5)$ & (6) & (7) & $(8)$ \\
\hline Trade Uncertainty & $\begin{array}{c}24.642 * * * \\
(2.906)\end{array}$ & $\begin{array}{c}26.856 * * * \\
(2.621)\end{array}$ & $\begin{array}{c}27.649 * * * \\
(78.426)\end{array}$ & $\begin{array}{c}23.815 * * * \\
(3.576)\end{array}$ & $\begin{array}{c}24.985 * * * \\
(3.064)\end{array}$ & $\begin{array}{c}26.315 * * * \\
(2.494)\end{array}$ & $\begin{array}{c}511.768 * * * \\
(78.426)\end{array}$ & $\begin{array}{c}28.176 * * * \\
(2.887)\end{array}$ \\
\hline Quality of Education & $\begin{array}{c}-10.581 * * * \\
(0.847)\end{array}$ & $\begin{array}{c}-10.826 * * * \\
(0.864)\end{array}$ & $\begin{array}{c}-10.763 * * * \\
(0.908)\end{array}$ & $\begin{array}{c}-10.838 * * * \\
(0.847)\end{array}$ & $\begin{array}{c}-10.596^{* * * *} \\
(0.895)\end{array}$ & $\begin{array}{c}-10.642 * * * \\
(0.919)\end{array}$ & $\begin{array}{c}-11.226 * * * \\
(0.815)\end{array}$ & $\begin{array}{c}-10.966 * * * \\
(0.851)\end{array}$ \\
\hline Quantity of Education & $\begin{array}{c}-0.169 * * \\
(0.074)\end{array}$ & $\begin{array}{c}-0.165^{* *} \\
(0.067)\end{array}$ & $\begin{array}{c}-0.169 * * \\
(0.070)\end{array}$ & $\begin{array}{c}-0.198 * * \\
(0.078)\end{array}$ & $\begin{array}{c}-0.206 * * * \\
(0.079)\end{array}$ & $\begin{array}{c}-0.159 * * \\
(0.068)\end{array}$ & $\begin{array}{c}-0.152 * * * \\
(0.065)\end{array}$ & $\begin{array}{c}-0.149 * * \\
(0.066)\end{array}$ \\
\hline Trade Uncertainty * Quality of Edu. & $\begin{array}{c}-2.546^{* * * *} \\
(0.565)\end{array}$ & $\begin{array}{c}-2.587 * * * \\
(0.552)\end{array}$ & $\begin{array}{c}-1.518 * * \\
(0.653)\end{array}$ & $\begin{array}{c}-2.553 * * * \\
(0.558)\end{array}$ & $\begin{array}{c}-1.833 * * * \\
(0.610)\end{array}$ & $\begin{array}{c}-1.932 * * * \\
(0.670)\end{array}$ & $\begin{array}{l}-18.410 \\
(12.871)\end{array}$ & $\begin{array}{c}-2.528 * * * \\
(0.590)\end{array}$ \\
\hline Trade Uncertainty * Quantity of Edu. & $\begin{array}{c}-0.124 * * * \\
(0.031)\end{array}$ & $\begin{array}{c}-0.147 * * * \\
(0.031)\end{array}$ & $\begin{array}{c}-0.195^{* * * *} \\
(0.032)\end{array}$ & $\begin{array}{c}-0.119 * * * \\
(0.037)\end{array}$ & $\begin{array}{c}-0.155^{* * * *} \\
(0.031)\end{array}$ & $\begin{array}{c}-0.164 * * * \\
(0.670)\end{array}$ & $\begin{array}{c}-4.444 * * * \\
(0.987)\end{array}$ & $\begin{array}{c}-0.164 * * * \\
(0.036)\end{array}$ \\
\hline GDP per Capita & - & - & $\begin{array}{l}-1.024 \\
(1.247)\end{array}$ & - & - & & - & - \\
\hline GDP per Capita $*$ Trade Uncertainty & - & - & $\begin{array}{c}-3.587 * * * \\
(0.654)\end{array}$ & - & - & & - & - \\
\hline GDP per Worker & - & - & - & $\begin{array}{c}0.001 \\
(0.001)\end{array}$ & - & & - & - \\
\hline GDP per Worker $*$ Trade Uncertainty & - & - & - & $\begin{array}{c}0.001 * * * \\
(0.000)\end{array}$ & - & & - & - \\
\hline Capital/Ratio & & & & & $\begin{array}{c}-0.048 * * * \\
(0.020)\end{array}$ & & & \\
\hline Capital/Ratio $*$ Trade Uncertainty & & & & & $\begin{array}{c}-0.054 * * * \\
(0.010)\end{array}$ & & & \\
\hline Internet Users & & & & & & $\begin{array}{l}-0.020 \\
(0.023)\end{array}$ & & \\
\hline Internet Users $*$ Trade Uncertainty & & & & & & $\begin{array}{c}-0.026 \\
(0.014)\end{array}$ & & \\
\hline R2/Adj. R2 & $0.533 / 0.502$ & $0.503 / 0.505$ & $0.533 / 0.532$ & $0.535 / 0.523$ & $0.547 / 0.541$ & $0.507 / 0.502$ & $0.463 / 0.469$ & $0.495 / 0.491$ \\
\hline Observations/Years/Countries & $635 / 32 / 61$ & $635 / 32 / 61$ & $624 / 32 / 61$ & $601 / 29 / 61$ & $601 / 29 / 61$ & $635 / 31 / 61$ & $635 / 32 / 61$ & $635 / 32 / 61$ \\
\hline
\end{tabular}

Alternative estimation methods: (1) fixed time and (2) random time period estimations. Adding as a control variable: (3) GDP per capita, (4) GDP per worker and (5) capital-

labour ratio, (6) Internet users per 100 people and its (respected) interaction terms with trade uncertainty. Alternative gravity equation, adding: (7) the first lag of the dependant variable and (8) a dummy variable for countries which use US dollars as an official currency following Novy (2013). The data to create this dummy is from Ilzetski et al (2010), results reported in (8) are when the dummy variable takes the value of 1, if the country of reference have adopted the US currency as the official currency (described as exchange rate arrangement with no separate legal tender). Huber robust standard errors (shown in parentheses) are clustered at the country level. *** and $* *$ denotes significance at the $1 \%$ and $5 \%$ level, respectively. 
Data Appendix Table 1. Description of Variables (Equation 1)

Dependant Variable

\begin{tabular}{|c|c|c|}
\hline Variable & Description & Source \\
\hline \multirow{2}{*}{$\log \left(\frac{\text { Bilateral trade }}{N G D P}\right)_{i t}$} & \multirow{2}{*}{$\begin{array}{l}\text { Logarithm of bilateral exports plus imports between } \\
\text { country } i \text { and the US divided by nominal gross } \\
\text { domestic product. }\end{array}$} & \multirow{3}{*}{$\begin{array}{l}\text { The US } \\
\text { Census } \\
\text { Bureau } \\
\text { and WDI }\end{array}$} \\
\hline & & \\
\hline \multicolumn{2}{|l|}{ Independent Variables } & \\
\hline Variable & Description & Source \\
\hline Population $_{\text {it }}$ & $\begin{array}{l}\text { Country's } i \text { population. All residents regardless of } \\
\text { legal status or citizenship. }\end{array}$ & WDI \\
\hline Dististance $_{\mathrm{i}}$ & $\begin{array}{l}\text { Distance of country } i \text { to the US (population-weighted } \\
\text { great circle distance between large cities of the two } \\
\text { countries), measure in kilometres. }\end{array}$ & CEPII \\
\hline Area $_{\mathrm{i}}$ & Country's area measure in square kilometres & CEPII \\
\hline Border $_{i}$ & $\begin{array}{l}\text { Dummy variable which takes the value of } 1 \text { if the } \\
\text { country has a border with the US and } 0 \text { otherwise }\end{array}$ & CEPII \\
\hline Locked $_{\mathrm{i}}$ & $\begin{array}{l}\text { Dummy variable which takes the value of } 1 \text { if the } \\
\text { country has access to open sea and } 0 \text { otherwise. }\end{array}$ & CEPII \\
\hline Colonial $_{\mathrm{i}}$ & $\begin{array}{l}\text { Dummy variable which takes the value of } 1 \text { if country } i \\
\text { has beena British colony and } 0 \text { otherwise }\end{array}$ & CEPII \\
\hline Freetrade $_{i t}:$ & $\begin{array}{l}\text { Dummy variable which takes the value of } 1 \text { if country } i \\
\text { has a free trade agreement with the US and } 0 \text { otherwise } \\
\text { (see dates in table } 2 \text { ) }\end{array}$ & WTO \\
\hline
\end{tabular}

Note: WDI: World Bank Indicators, CEPII: Centre d'Etudes Prospectives et d'Informations Internationales. WTO: World Trade Organization.

Data Appendix Table 2. Free Trade Agreements Dummy Variable Dates

\begin{tabular}{lll}
\hline $\begin{array}{l}\text { Countries Free Trade Agreement with } \\
\text { the US }\end{array}$ & $\begin{array}{l}\text { Date of Agreement Entered } \\
\text { into Force }\end{array}$ & Dummy Variable \\
\hline Australia & January 1, 2005. & 2005-End sample \\
NAFTA: Canada-Mexico & January 1, 1994. & 1994-End sample \\
Chile & January 1, 2004 & 2004-End sample \\
Colombia & May 1, 2012 & 2012-End sample \\
Israel & April 22, 1985 & 1985-End sample \\
Jordan & December 7, 2001 & 2002-End sample \\
Morocco & January 1, 2006 & 2006-End sample \\
Panama & October 31, 2012 & 2013-End sample \\
Peru & February 1, 2007 & 2007-End sample \\
Central America (Costa Rica, Dominican & October 2012 & 2013-End sample \\
Rep. Honduras, El Salvador and & & \\
Nicaragua) & & \\
\hline
\end{tabular}


Data Appendix Table 3. Description of Variables (Equation 2)

Dependant Variable

\begin{tabular}{|c|c|c|}
\hline Variable & Description & Source \\
\hline $\begin{array}{l}\operatorname{Gini}_{\text {it }} \\
\text { or }\end{array}$ & $\begin{array}{l}\text { Measure the extent to which the distribution of } \\
\text { income among individuals or households within } \\
\text { an economy deviates from a perfectly equal } \\
\text { distribution. }\end{array}$ & WDI \\
\hline $\mathrm{L} 20_{\text {it }}$ & $\begin{array}{l}\text { Percentage share of income of the poorest } 20 \% \\
\text { of population. }\end{array}$ & WDI \\
\hline \multicolumn{3}{|l|}{ Independent Variables } \\
\hline Variable & Description & Source \\
\hline Trade Uncertainty $_{i}$ & Residual of Equation 1 & Equation 1 \\
\hline $\begin{array}{l}\text { Quantity of Education } \\
\text { (Adjusted Enrolment } \\
\text { Rate (Primary)) }\end{array}$ & $\begin{array}{l}\text { Total number of students of the official primary } \\
\text { school age group who are enrolled at primary } \\
\text { education, expressed as a percentage of the } \\
\text { corresponding population. }\end{array}$ & WDI \\
\hline
\end{tabular}

Quality of Education Measures

Cognitive Skills

Lower Secondary

Education

Basic Education

Top Education
Average test score in math and science, primary through end of secondary school, all years (scaled to PISA scale divided by 100).

Average test score in math and science, only lower secondary, all years (scaled to PISA scale divided by 100).

Share of students reaching basic literacy (based on average test scores in math and science, primary through end of secondary school, all years).

Share of top-performing students (based on average test scores in math and science, primary through end of secondary school, all years).
Hanushek and

Woessmann (2009)

Hanushek and Woessmann (2009)

Hanushek and

Woessmann

(2009)

Hanushek and Woessmann (2009) 
Data Appendix 4. Description of Variables (Robustness Analysis)

Additional Control Variables

\begin{tabular}{|c|c|c|}
\hline Variable & Description & Source \\
\hline GDP per Capita & $\begin{array}{l}\text { Gross domestic product divided by midyear } \\
\text { population. Data are in current U.S. dollars. }\end{array}$ & WDI \\
\hline GDP per Worker & $\begin{array}{l}\text { GDP per person employed is gross domestic } \\
\text { product (GDP) divided by total employment in } \\
\text { the economy. Purchasing power parity (PPP) } \\
\text { GDP is GDP converted to } 2011 \text { constant } \\
\text { international dollars using PPP rates. }\end{array}$ & WDI \\
\hline Capital-Labour Ratio & $\begin{array}{l}\text { Is approximated by multiplying gross capital } \\
\text { formation (as \% of GDP) times GDP (PPP) } \\
\text { international dollars. Results are divided by } \\
\text { people employed (inter-temporal average) in the } \\
\text { country. }\end{array}$ & WDI \\
\hline $\begin{array}{l}\text { Official currency (US } \\
\text { dollar) }\end{array}$ & $\begin{array}{l}\text { Dummy variable which takes the value of } 1 \text { if the } \\
\text { country of reference has adopted the US dollar as } \\
\text { an official currency and } 0 \text { otherwise. }\end{array}$ & $\begin{array}{l}\text { Ilzetski, } \\
\text { Reinhart, and } \\
\text { Rogoff (2010) }\end{array}$ \\
\hline $\begin{array}{l}\text { Internet users (per } 100 \\
\text { people) }\end{array}$ & $\begin{array}{l}\text { Internet users are individuals who have used the } \\
\text { Internet (from any location) in the last } 12 \text { months. } \\
\text { Internet can be used via a computer, mobile } \\
\text { phone, personal digital }\end{array}$ & WDI \\
\hline
\end{tabular}


Data Appendix Table 5. List of Countries (Equation 1)

\begin{tabular}{|c|c|c|c|}
\hline Albania & El Salvador & Malawi & Sri Lanka \\
\hline Algeria & Estonia & Malaysia & St. Lucia \\
\hline Angola & Ethiopia & Maldives & Sudan \\
\hline Argentina & Fiji & Mali & Suriname \\
\hline Armenia & Finland & Mauritania & Swaziland \\
\hline Australia & France & Mauritius & Sweden \\
\hline Austria & Gabon & Mexico & Switzerland \\
\hline Azerbaijan & Gambia, The & Micronesia, Fed. Sts. & Syrian Arab Republic \\
\hline Bangladesh & Georgia & Moldova & Tajikistan \\
\hline Belarus & Germany & Mongolia & Tanzania \\
\hline Belgium & Ghana & Montenegro & Timor-Leste \\
\hline Belize & Greece & Morocco & Togo \\
\hline Benin & Guatemala & Mozambique & Tonga \\
\hline Bhutan & Guinea & Namibia & Trinidad and Tobago \\
\hline Bolivia & Guinea-Bissau & Nepal & Tunisia \\
\hline Bosnia and Herz. & Guyana & Netherlands & Turkey \\
\hline Botswana & Haiti & Nicaragua & Turkmenistan \\
\hline Brazil & Honduras & Niger & Uganda \\
\hline Bulgaria & Hungary & Nigeria & Ukraine \\
\hline Burkina Faso & Iceland & Norway & United Kingdom \\
\hline Burundi & India & Pakistan & Uruguay \\
\hline Cabo Verde & Indonesia & Palau & Uzbekistan \\
\hline Cambodia & Iran, Islamic Rep. & Panama & Venezuela, RB \\
\hline Cameroon & Ira & Papua New Guinea & Vietnam \\
\hline Canada & Ireland & Paraguay & Zambia \\
\hline Central African Rep. & Israel & Peru & \\
\hline Chad & Italy & Philippines & \\
\hline Chile & Jamaica & Poland & \\
\hline China & Japan & Portugal & \\
\hline Colombia & Jordan & Romania & \\
\hline Comoros & Kazakhstan & Russian Federation & \\
\hline Congo, Dem. Rep. & Kenya & Rwanda & \\
\hline Congo, Rep. & Kiribati & Samoa & \\
\hline Costa Rica & Kosovo & Sao Tome and Prin. & \\
\hline Cote d'Ivoire & Kyrgyz Republic & Senegal & \\
\hline Croatia & Lao PDR & Serbia & \\
\hline Cyprus & Latvia & Seychelles & \\
\hline Czech Republic & Lesotho & Sierra Leone & \\
\hline Denmark & Liberia & Slovak Republic & \\
\hline Djibouti & Lithuania & Slovenia & \\
\hline Dominican Republic & Luxembourg & Solomon Islands & \\
\hline Ecuador & Macedonia, FYR & South Africa & \\
\hline Egypt, Arab Rep. & Madagascar & Spain & \\
\hline
\end{tabular}


Data Appendix Table 6. List of Countries (Equation 2)

\begin{tabular}{llll}
\hline Albania & Estonia & Latvia & Russia Federation \\
Argentina & Finland & Lithuania & Serbia \\
Armenia & France & Luxembourg & Slovak Republic \\
Australia & Germany & Macedonia & Slovenia \\
Austria & Ghana & Malaysia & South Africa \\
Belgium & Greece & Mexico & Spain \\
Botswana & Hungary & Moldova & Swaziland \\
Brazil & Iceland & Morocco & Sweden \\
Bulgaria & India & Netherland & Switzerland \\
Canada & Indonesia & Nigeria & Tunisia \\
Chile & Iran, Islamic Rep. & Norway & Turkey \\
China & Ireland & Peru & United Kingdom \\
Colombia & Israel & Philippines & Uruguay \\
Cyprus & Italy & Poland & \\
Denmark & Japan & Portugal & \\
Egypt, Arab Rep & Jordan & Romania & \\
\hline
\end{tabular}


Data Appendix Table 7. Descriptive Statistics

\begin{tabular}{|c|c|c|c|c|c|}
\hline Variable & $\begin{array}{l}\text { Equation } \\
\text { Number }\end{array}$ & Mean & Minimum & Maximum & $\begin{array}{l}\text { Standard } \\
\text { Deviation }\end{array}$ \\
\hline \multicolumn{6}{|l|}{ Dependant: } \\
\hline (Bilateral trade) & 1 & -7.72 & -1.21 & -15.77 & 2.69 \\
\hline $\log \left(\frac{\text { NGDP }}{\text { it }}\right)_{\text {it }}$ & & & & & \\
\hline Gini $_{\text {it }}$ & 2 & 39.83 & 16.23 & 99.91 & 10.30 \\
\hline $\mathrm{L} 20_{\text {it }}$ & - & 6.274 & 0.26 & 13.37 & 2.326 \\
\hline \multicolumn{6}{|l|}{ Independent Variables: } \\
\hline $\log \left(\right.$ Population $\left._{\mathrm{it}}\right)$ & 1 & 15.71 & 11.00 & 21.03 & 1.84 \\
\hline $\log \left(\right.$ Dististance $\left._{\mathrm{i}}\right)$ & 1 & 9.06 & 6.04 & 9.70 & 0.54 \\
\hline $\log \left(\right.$ Area $\left._{\mathrm{i}}\right)$ & 1 & 11.85 & 6.13 & 16.61 & 2.09 \\
\hline Trade Uncertainty $_{i}$ & 2 & -0.14 & -4.15 & 4.16 & 1.63 \\
\hline Quantity of Education ${ }_{i}$ : & 2 & 85.17 & 33.39 & 99.92 & 16.10 \\
\hline \multicolumn{6}{|c|}{ Quality of Education (Alternative Measures) } \\
\hline Cognitive Skills & 2 & 4.51 & 3.09 & 5.31 & 0.55 \\
\hline Lower Secondary Education & 2 & 4.49 & 2.68 & 5.39 & 0.59 \\
\hline Basic Education & 2 & 0.75 & 0.18 & 0.97 & 0.20 \\
\hline Top Education & 2 & 0.05 & 0.00 & 0.17 & 0.04 \\
\hline
\end{tabular}

